\title{
Laboratory diagnostics in the elderly: cardiovascular disease
}

\author{
A Sciacqua*, EJ Tassone, P Naccarato, L Greco, I Laino, S Miceli, F Perticone \\ From de Senectute: Age and Health Forum \\ Catanzaro, Italy. 5-7 December 2009
}

Increased life expectancy in industrialized countries has led to the progressive aging of the general population, this event is associated with a concomitant increase of Cardiovascular Disease (CVD) that represents not only the main cause of death but also one of the major causes of morbidity, inability and reduction of life quality in the elderly population.

In the Western countries, Arterial Hypertension (AH) affects more than $50 \%$ of the elderly, and Heart Failure (HF) represents the most frequent diagnosis among hospital discharges among the elderly. The prevalence of type 2 diabetes mellitus (DM) also increases in the elderly population, reaching about the $7-10 \%$. In this context, the role of laboratory diagnostics is fundamental to support the diagnosis, for monitoring drug therapy and its possible side effects. In patients with recent diagnosis of AI, it is crucial to perform a complete hemocromocytometric analysis, the evaluation of lipid and glucidic metabolism parameters, serum electrolytes, and creatinine and uric acid to evaluate renal function. Hemoglobin and hematocrit values can establish the presence of anemia, which can be a sign of renal disease. Fasting glucose can be used to define the diagnosis of $\mathrm{DM}$, and in patients with previous a diagnosis it is useful to control the metabolic status that is correlated to the development of cardiovascular complications. Moreover in hypertensive patients, the presence of high blood glucose levels can mask a secondary form of $\mathrm{AH}$, as do the potassium serum levels. In addition, in the elderly an impairment of the thyroid function should also be evaluated, as a possible cause of atrial fibrillation, that is the most frequent tachyarrhythmia in over 65 year olds.

Finally, the diagnosis of HF in the elderly with different comorbidities can represent a very strong challenge; in this case, laboratory diagnostics can support the

Geriatric Cardiovascular Disease Unit, Department of Clinical and Experimental Medicine, University Magna Græcia, Catanzaro, Italy clinician in the diagnostic and therapeutic process. It is advisable to measure BNP/NT-proBNP to exclude/confirm the diagnosis of HF in patients with ambiguous clinical signs and symptoms that can be confused with other clinical conditions. Moreover, it is important to dose some laboratory parameters related to renal function to monitor possible side effects of drugs employed in chronic HF (CHF). Thus, in the management of the elderly affected by CVD, the laboratory is crucial and the kind and the frequency of laboratory tests are above all oriented by the patient's clinical symptoms and signs, by the presence of target organ damage and the possible side effects of the employed drugs.

Published: 19 May 2010

doi:10.1186/1471-2318-10-S1-L26

Cite this article as: Sciacqua et al.: Laboratory diagnostics in the elderly: cardiovascular disease. BMC Geriatrics 2010 10(Suppl 1):L26.

\section{Submit your next manuscript to BioMed Central and take full advantage of: \\ - Convenient online submission \\ - Thorough peer review \\ - No space constraints or color figure charges \\ - Immediate publication on acceptance \\ - Inclusion in PubMed, CAS, Scopus and Google Scholar \\ - Research which is freely available for redistribution \\ Submit your manuscript at www.biomedcentral.com/submit}

